\title{
Inhibin in individual ovine follicles in relation to diameter and atresia
}

\author{
C. G. Tsonis, Helen Quigg, V. W. K. Lee, Lorraine Leversha, \\ A. O. Trounson* and J. K. Findlay
}

Medical Research Centre, Prince Henry's Hospital, Melbourne 3004 and * Department of Obstetrics and Gynaecology, Monash University, Queen Victoria Medical Centre, Melbourne 3000, Australia

\begin{abstract}
Summary. Inhibin activity was measured by bioassay in follicular fluid of 99 individual ovine follicles ranging from 1.4 to $6.8 \mathrm{~mm}$ diameter (used to calculate volume) and in various stages of atresia. Treatment of samples before assay with charcoal concentrations of $>1 \mathrm{mg} / \mathrm{ml}$ resulted in significant loss of inhibin activity.

The inhibin content of follicular fluid from individual follicles varied with follicular fluid volume but not with the degree of atresia, as assessed by morphological criteria. Inhibin concentration was not related to atresia, but was correlated with follicular fluid volume. However, aromatase activity in granulosa cells and oestradiol-17 $\beta$ concentration of follicular fluid, considered to be good indices of atresia, were highly correlated with both inhibin content and concentration in follicles $\geqslant 3.5 \mathrm{~mm}$ diameter.

Inhibin in ovine follicular fluid shows marked variation between follicles and it is suggested that this reflects a combination of the number and activity of granulosa cells within the follicle and the exit rate of inhibin from the follicle.
\end{abstract}

\section{Introduction}

Inhibin is a non-steroidal gonadal hormone capable of selective suppression of FSH release from the pituitary gland (Main, Davies \& Setchel, 1979). Follicular fluids from several species, including cow (de Jong \& Sharpe, 1976; Welschen, Hermans, Dullaart \& de Jong, 1977; Henderson \& Franchimont, 1981), sheep (Scott, Quigg, Trounson, Tsonis \& Findlay, 1980a), pig (Marder, Channing \& Schwartz, 1977; Lorenzen, Dworkin, Schwartz \& Channing, 1978), monkey (Channing, Anderson \& Hodge, 1980) and man (Chari, Hopkinson, Daume \& Sturm, 1979; Channing et al., 1981), have been found to contain inhibin activity.

Data from the literature are contradictory concerning the levels of ovarian inhibin during follicular development, and the studies have usually been performed on pools of fluid rather than on fluid from individual follicles. It has been claimed that the concentration of inhibin decreases with growth of follicles in the pig (Lorenzen et al., 1978) and the cow (Henderson \& Franchimont, 1981). In contrast, Welschen et al. (1977) detected inhibin in small bovine follicles but measured higher concentrations in medium and large follicles. Relatively little is known about the relationship between inhibin and follicular atresia. One study of the human follicle (Channing et al., 1981) and some preliminary data on sheep follicles (Scott et al., 1980a) indicate a decrease in inhibin concentrations with atresia.

There is indirect evidence that ovarian follicular inhibin may be an important regulator of FSH in the ewe (Goodman, Pickover \& Karsch, 1981 ; Cummins, O'Shea, Bindon, Lee \& Findlay, 1983). 
The aim of this study was to measure the content and concentration of inhibin in follicular fluid of individual sheep follicles and relate this to the diameter and stage of atresia of the follicle.

\section{Materials and Methods}

\section{Inhibin bioassay}

Inhibin activity was measured by an in-vitro pituitary cell culture system using FSH cell content as the end point (Scott, Burger \& Quigg, 1980b). Unknowns were compared to a reference preparation derived from ovine testicular lymph protein (OTLP-6) which was assigned a potency of $1 \mathrm{U} / \mathrm{mg}$ (Eddie, Baker, Higginson \& Hudson, 1979). The standard curve in quadruplicate and unknowns in triplicate were assayed in at least 3 dilutions to generate parallel FSH inhibition curves (Text-fig. 1). Ovine follicular fluid had no significant effects on the LH content of the pituitary cells (Text-fig. 1). Relative potencies were calculated for those samples that showed no significant departure from parallelism to the reference preparation, analysed by regression analysis and parallel line assay statistics (Borth, 1976).

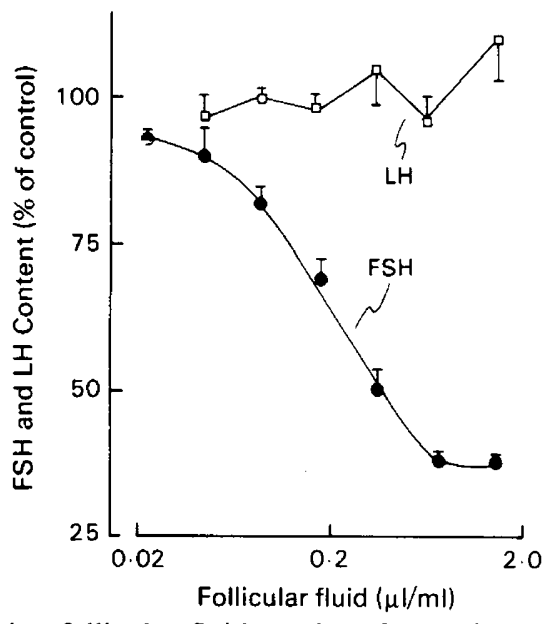

Text-fig. 1. Effect of ovine follicular fluid on the FSH and LH content of pituitary cells.

\section{Isolation of follicles}

Sheep ovaries were obtained from a local abattoir, placed in $0.154 \mathrm{M}-\mathrm{NaCl}$ (saline) containing $50 \mathrm{U}$ kanamycin (Sigma, Melbourne, Australia) $/ \mathrm{ml}$ plus $0.1 \%$ (w/v) glucose (BDH Chemicals, Melbourne, Australia) and transported on ice to the laboratory. Individual follicles were dissected and classified according to diameter, measured by a calibrated eyepiece graticule to the nearest 0.5 $\mathrm{mm}$ or $0.1 \mathrm{~mm}$ (by taking two diameters perpendicular to each other and averaging). Only follicles $\geqslant 3.5 \mathrm{~mm}$ in which diameter was measured to the nearest $0.5 \mathrm{~mm}$ were used to determine inhibin content, whereas those measured to the nearest $0.1 \mathrm{~mm}$ were used to determine content and concentration. Since the protein content of follicular fluid measured by the method of Lowry, Rosebrough, Farr \& Randall (1951) did not vary significantly with atresia in follicles $<3.5 \mathrm{~mm}$ diameter (Table 4), inhibin concentration in these follicles $(N=47)$ measured to the nearest 0.5 $\mathrm{mm}$ and $0.1 \mathrm{~mm}$ diameter was expressed as $U / \mathrm{mg}$ protein. In addition, inhibin concentration in follicular fluid was determined small follicles measured to the nearest $0.1 \mathrm{~mm}$ diameter. The volume of fluid (V) contained within each follicle was calculated from the diameter of the follicle (D) by the formula, $\mathrm{V}=0.52(\mathrm{D})^{2.7}$ (Carson, Findlay, Clarke \& Burger, 1981). The stage of atresia 
was assessed by morphological criteria (Carson, Findlay, Burger \& Trounson, 1979), and graded I$\mathrm{V}$, follicles of class I being non-atretic and those of class $\mathrm{V}$ being terminally atretic.

\section{Aromatase assay}

The aromatase activity ( $\mathrm{pmol}$ oestradiol-17/ $/ 10^{6}$ viable granulosa cells $/ \mathrm{h}$ ) was measured in vitro by incubating $0.5-17.4 \times 10^{4}$ granulosa cells for $1 \mathrm{~h}$ in the presence of $0.1 \mu \mathrm{M}$-testosterone in medium 199 (Tsonis \& Findlay, 1981). The oestradiol content of the media and of follicular fluid was measured (after extraction) by radioimmunoassay (WHO Matched Assay Reagents). The within- and between assay coefficients of variation for 33 consecutive oestradiol assays were $<15 \%$ $(1.5-86 \mathrm{fmol} /$ tube) and $10.7 \%$ (at $20 \mathrm{fmol} /$ tube) respectively.

\section{Experiment 1}

The aim of this experiment was to determine the optimum concentration of charcoal which removed most of the steroids, without affecting inhibin activity in follicular fluid.

Four $5 \mathrm{~mm}$ follicles of stages I-III atresia were placed in $100 \mu \mathrm{l}$ Dulbecco phosphate-buffered saline (DPBS; CSL, Melbourne, Australia) and punctured several times with a sharp needle. Each sample was centrifuged ( $7000 \mathrm{~g}$ for $2 \mathrm{~min}$ ) to remove tissue debris. Portions of the supernatant were further diluted and treated with various concentrations, up to $1.0 \mathrm{mg} / \mathrm{ml}$, of charcoal coated with $0.01 \%$ dextran (Lee, McMaster, Quigg, Findlay \& Leversha, 1981) for $30 \mathrm{~min}$ at $4^{\circ} \mathrm{C}$ and centrifuged as above. The supernatants were assayed for inhibin activity.

The ability of similar concentrations of charcoal to remove steroid from diluted follicular fluid was assessed by adding 8000 c.p.m. ${ }^{125} \mathrm{I}$-labelled testosterone to duplicate aliquants of follicular fluid from 3 individual follicles of $3 \mathrm{~mm}$ diameter and at stage I or II of atresia and measuring the radioactivity remaining after charcoal treatment.

Because the values for inhibin in ovine follicular fluid from this experiment appeared to be much higher than those in our earlier study (Scott $e t$ al., 1980a) and those reported by Henderson \& Franchimont (1981) for cow follicles, we compared treatment of follicular fluid with 1 and $10 \mathrm{mg}$ charcoal $/ \mathrm{ml}$. Cow and sheep ovaries were obtained, dissected and follicles classified as above. One small $(2.2 \mathrm{~mm})$ and one large $(5.8 \mathrm{~mm})$ ovine follicle and one small $(3.4 \mathrm{~mm})$ and one large $(6.4 \mathrm{~mm})$ bovine follicle were individually ruptured in $250 \mu \mathrm{l}$ medium 199 , buffered with $20 \mathrm{mM}$-Hepes $(N-2-$ hydroxyethylpiperazine- $N^{\prime}-2$-ethanesulphuric acid; CSL) containing $50 \mathrm{U}$ kanamycin $/ \mathrm{ml}$. Aliquants of $100 \mu$ l of each sample were subjected to two charcoal regimens: (a) $1 \mathrm{mg} / \mathrm{ml}$ containing $0.01 \%(\mathrm{w} / \mathrm{v})$ dextran for $10 \mathrm{~min}$ at room temperature, $30 \mathrm{~min}$ at $4^{\circ} \mathrm{C}$ and then centrifuged at $7000 \mathrm{~g}$ for $2 \mathrm{~min}$ (our method); or (b) $10 \mathrm{mg} / \mathrm{ml}$ containing $0.1 \%(\mathrm{w} / \mathrm{v})$ dextran, mixed for $16 \mathrm{~h}$ at $4^{\circ} \mathrm{C}$ and centrifuged at $3000 \mathrm{~g}$ for $30 \mathrm{~min}$ (adapted from Henderson \& Franchimont, 1981). The supernatants were serially diluted and assayed for inhibin activity.

\section{Experiment 2}

In this experiment, we measured inhibin content and concentration in follicular fluid from individual ovine follicles in relation to diameter and atresia. Sheep ovaries were obtained as described above. Individual follicles were hemisected in $200 \mu \mathrm{l}$ Medium 199 buffered with $20 \mathrm{mM}-$ Hepes (containing $50 \mathrm{U}$ kanamycin $/ \mathrm{ml}$ ), centrifuged $(800 \mathrm{~g}$ for $5 \mathrm{~min}$ ) and the supernatant stored at $-15^{\circ} \mathrm{C}$. Before assay, samples were treated with $0.01 \%$ dextran-coated charcoal at $1 \mathrm{mg} / \mathrm{ml}$ final concentration.

The volume of follicular fluid released into the medium was accounted for when calculating inhibin content and concentration. The data were transformed into logarithms and then analysed using an unpaired $t$ test and ANOVA and Duncan's test. Follicles were divided into small $(<3.5$ $\mathrm{mm}$ ) and large ( $\geqslant 3.5 \mathrm{~mm}$ ) groups, using $3.5 \mathrm{~mm}$ diameter as a cut-off point because of functional changes in steroidogenesis and LH receptor number at this diameter (Carson et al. 1979, 1981). 


\section{Results}

Experiment 1

At charcoal concentrations $\geqslant 0.5 \mathrm{mg} / \mathrm{ml}$, approximately $1 \%$ of ${ }^{125} \mathrm{I}$-labelled testosterone remained in the diluted follicular fluid of 3 individual follicles (Table 1). The inhibin potencies and slopes of the dose-response curves for 4 different follicles were not significantly altered by the charcoal concentration $(0-1 \mathrm{mg} / \mathrm{ml}$ ) (Table 2 ). At least 10 -fold more inhibin activity was measured in ovine and bovine follicular fluid after charcoal treatment of $1 \mathrm{mg} / \mathrm{ml}$ compared with $10 \mathrm{mg} / \mathrm{ml}$ (Table 3).

We therefore chose a charcoal concentration of $1 \mathrm{mg} / \mathrm{ml}$ to treat follicular fluid before measuring inhibin activity.

Table 1. The percentage of ${ }^{125}$ I-labelled testosterone remaining after dextran-coated charcoal treatment of follicular fluid from 3 individual ovine follicles

\begin{tabular}{cccccc}
\hline $\begin{array}{c}\text { Follicle } \\
\text { diam. } \\
(\mathrm{mm})\end{array}$ & \begin{tabular}{c} 
Stage $\begin{array}{c}\text { of } \\
\text { atresia }\end{array}$ \\
\cline { 3 - 6 }
\end{tabular} & \multicolumn{4}{c}{ Charcoal conc. (mg/ml) } \\
\hline 3 & I & 4.8 & 0.25 & 0.5 & $1 \cdot 0$ \\
3 & I & 5.3 & 1.6 & $1 \cdot 1$ & $1 \cdot 1$ \\
3 & II & 3.8 & 1.3 & 0.8 & 0.8 \\
\hline
\end{tabular}

Table 2. Inhibin activity $(\mathrm{kU} / \mathrm{ml})$ in follicular fluid of ovine follicles treated with various concentrations of dextran-coated charcoal

\begin{tabular}{|c|c|c|c|c|}
\hline \multirow{2}{*}{$\begin{array}{c}\text { Follicle } \\
\text { diam. } \\
(\mathrm{mm})\end{array}$} & \multirow{2}{*}{$\begin{array}{c}\text { Stage } \\
\text { of } \\
\text { atresia }\end{array}$} & \multicolumn{3}{|c|}{ Charcoal conc. $(\mathrm{mg} / \mathrm{ml})$} \\
\hline & & 0 & 0.5 & $1 \cdot 0$ \\
\hline 5 & II & $\begin{array}{l}37.9(21 \cdot 5-64 \cdot 6) \\
\{18 \cdot 5\}\end{array}$ & $\begin{array}{l}38 \cdot 1(22 \cdot 6-63 \cdot 0) \\
\{18 \cdot 9\}\end{array}$ & $\begin{array}{l}33 \cdot 6(19 \cdot 8-57 \cdot 0) \\
\{24 \cdot 0\}\end{array}$ \\
\hline 5 & I & $\begin{array}{l}63 \cdot 4(48 \cdot 5-83 \cdot 1) \\
\{20 \cdot 1\}\end{array}$ & $\begin{array}{l}42 \cdot 8(32 \cdot 7-55 \cdot 9) \\
\{15 \cdot 6\}\end{array}$ & $\begin{array}{l}60 \cdot 8(45 \cdot 2-81 \cdot 9) \\
\{20 \cdot 4\}\end{array}$ \\
\hline 5 & II & $\begin{array}{l}35 \cdot 2(27 \cdot 0-46 \cdot 3) \\
\{17 \cdot 8\}\end{array}$ & $\begin{array}{l}45.4(35 \cdot 0-59 \cdot 1) \\
\{16 \cdot 0\}\end{array}$ & $\begin{array}{l}34 \cdot 3(25 \cdot 6-46 \cdot 3) \\
\{25 \cdot 4\}\end{array}$ \\
\hline 5 & III & $\begin{array}{l}31 \cdot 1(22 \cdot 3-43 \cdot 2) \\
\{15 \cdot 7\}\end{array}$ & $\begin{array}{l}18 \cdot 6(12 \cdot 4-27 \cdot 6) \\
\{38 \cdot 5\}\end{array}$ & $\begin{array}{l}32 \cdot 7(24.0-44.4) \\
\{18.0\}\end{array}$ \\
\hline
\end{tabular}

Index of precision $(\lambda)=-0 \cdot 15$.

Values represent inhibin potency $(95 \%$ confidence limits) and numbers in braces are slope values.

\section{Experiment 2}

Inhibin and follicular diameter. Inhibin content varied markedly between and within follicles of the same diameter and ranged from 3 to $1140 \mathrm{U} /$ follicle (Text-fig. 2a). There was a positive relationship (ln $y=1.09 \ln x+1.85)$ between inhibin content $(y)$ and follicular fluid volume $(x),(r$ $=0.85 ;$ d.f. $=98 ; P<0.001)$. When these follicles were distinguished as large $(\geqslant 3.5 \mathrm{~mm})$ or small $(<3.5 \mathrm{~mm})$, there was a significantly higher $(P<0.001)$ inhibin content (mean \pm s.e.m.) in the large $(448 \pm 62 \mathrm{U} /$ follicle, $\mathrm{N}=27)$ than in the small follicles $(61 \pm 7 \mathrm{U} /$ follicle; $N=72)$.

The inhibin concentration in follicular fluid was determined only in those follicles in which diameter was measured to the nearest $0.1 \mathrm{~mm}(\mathrm{~N}=43)$, and not those measured to the nearest 0.5 $\mathrm{mm}$, since the accuracy of measuring follicle diameter is critical in calculating follicular volume and 
hence inhibin concentration. Inhibin concentration varied from 2 to $29 \mathrm{kU} / \mathrm{ml}$ and increased with follicular diameter and hence fluid volume $(\ln y=0.24 \ln x+1.47)(r=0.35 ;$ d.f. $=42 ; P<0.05)$ (Text-fig. 2b). There was no significant difference $(P>0.05)$ in inhibin concentration (mean \pm s.e.m.) between small $(8.2 \pm 1.2 \mathrm{kU} / \mathrm{ml} ; \mathrm{N}=23)$ and large $(12.3 \pm 1.8 \mathrm{kU} / \mathrm{ml} ; \mathrm{N}=20)$ follicles.

Table 3. A comparison of two methods of charcoal treatment of ovine and bovine follicular fluid on the inhibin concentration $(\mathrm{kU} / \mathrm{ml})$ (mean, 95\% confidence limits; index of preci$\operatorname{sion}(\lambda)=-0 \cdot 14)$

\begin{tabular}{|c|c|c|}
\hline \multirow{2}{*}{$\begin{array}{l}\text { Follicle type } \\
\text { and diameter }\end{array}$} & \multicolumn{2}{|c|}{ Charcoal conc. $(\mathrm{mg} / \mathrm{ml})$} \\
\hline & 1 & 10 \\
\hline Ovine, $2.2 \mathrm{~mm}$ & $\begin{array}{l}5 \cdot 3 \\
(4 \cdot 0-7 \cdot 1)\end{array}$ & $\leqslant 1 \cdot 2^{a}$ \\
\hline Ovine, $5.8 \mathrm{~mm}$ & $\begin{array}{l}17 \cdot 0 \\
(12 \cdot 7-22 \cdot 9)\end{array}$ & $\begin{array}{l}1 \cdot 6 \\
(1 \cdot 2-2 \cdot 3)\end{array}$ \\
\hline Bovine, $3.4 \mathrm{~mm}$ & $\begin{array}{l}2 \cdot 7 \\
(2 \cdot 2-3 \cdot 3)\end{array}$ & $\leqslant 0.4^{b}$ \\
\hline Bovine, $6.4 \mathrm{~mm}$ & $\begin{array}{l}5 \cdot 6 \\
(4 \cdot 6-6 \cdot 8)\end{array}$ & $\begin{array}{l}0.5 \\
(0.3-0.7)\end{array}$ \\
\hline
\end{tabular}

a,b These values were calculated, based on the sensitivity of the inhibin bioassay $(0 \cdot 1 \mathrm{U} /$ well) and volume of follicular fluid (highest dose of follicular fluid used in culture).
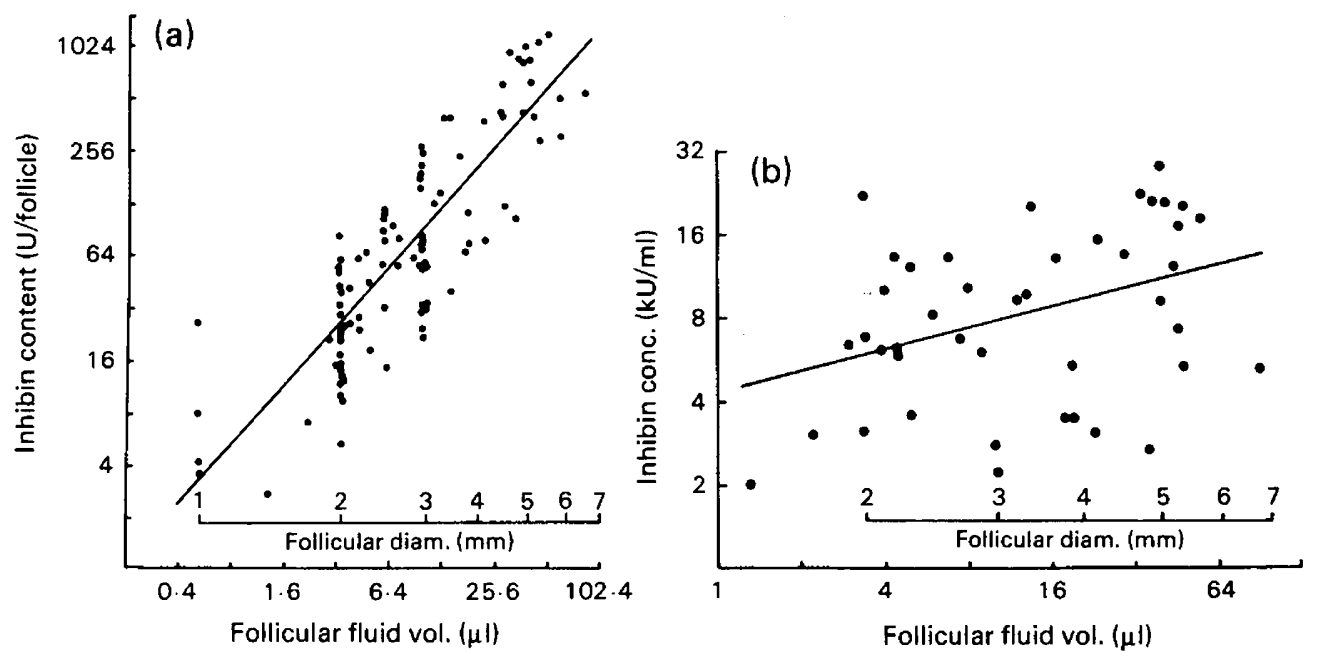

Text-fig. 2. Relationship between inhibin content (a) and inhibin concentration (b) and follicular fluid volume (and follicular diameter) of individual ovine follicles. In (a), $\ln y=1.09$ $\ln x+1.85 ; r=0.85, P<0.001(\mathrm{~N}=99)$. In (b), $\ln y=0.24 \ln x+1.47 ; r=0.35, P<0.05$ $(\mathrm{N}=43)$.

Inhibin activity and atresia. There were no significant differences between inhibin content, inhibin concentration or protein content in follicular fluid of small follicles in the various stages of atresia (Table 4). In large follicles $(\geqslant 3.5 \mathrm{~mm})$, inhibin content was also not significantly different in the different stages of atresia (Table 5). Furthermore, inhibin concentration in follicular fluid from follicles in stages I and II (healthy or early in atresia) and follicles in stages III, IV and V (atretic) showed no significant difference in the small $(<3.5 \mathrm{~mm})$ or large $(\geqslant 3.5 \mathrm{~mm})$ size groups (Table 6). 
Table 4. Inhibin content, concentration and protein content in follicular fluid of small follicles $(<3 \cdot 5$ $\mathrm{mm}$ ) at various stages of atresia (see text)

\begin{tabular}{|c|c|c|c|c|c|c|}
\hline & \multicolumn{5}{|c|}{ Stage of atresia } & \multirow[b]{2}{*}{ F value } \\
\hline & 1 & II & III & IV & $\mathrm{v}$ & \\
\hline $\begin{array}{l}\text { Inhibin content } \\
\text { (U/follicle) }\end{array}$ & $54 \underset{(17)}{ \pm} 18$ & $60 \underset{(18)}{ \pm}$ & $\begin{array}{c}65 \pm 13 \\
(16)\end{array}$ & $37 \underset{(9)}{ \pm}$ & $57 \underset{(11)}{ \pm} 16$ & $F_{4,66}=0.32$ \\
\hline $\begin{array}{l}\text { Inhibin conc. } \\
\text { (U/mg protein) }\end{array}$ & $201 \pm 51$ & $108 \underset{(9)}{ \pm} 29$ & $146 \pm 27$ & $112 \pm 21$ & $\begin{array}{c}106 \pm 17 \\
(10)\end{array}$ & $F_{4.42}=1.64$ \\
\hline $\begin{array}{l}\text { Protein content } \\
(\mu \mathrm{g} / \text { follicle })\end{array}$ & $\begin{array}{c}346 \pm 92 \\
(10)\end{array}$ & $411 \underset{(9)}{ \pm} 110$ & $48 \underset{(10)}{ \pm} 69$ & $384 \underset{(8)}{ \pm} 91$ & $\begin{array}{c}494 \pm 93 \\
(10)\end{array}$ & $F_{4.42}=0.52$ \\
\hline
\end{tabular}

Values represent mean \pm s.e.m. and numbers in parentheses refer to number of follicles.

Table 5. Inhibin content (U/follicle) in follicular fluid of large $(\geqslant 3.5 \mathrm{~mm})$ ovine follicles at various stages of atresia

\begin{tabular}{|c|c|c|c|c|c|}
\hline \multicolumn{5}{|c|}{ Stage of atresia } & \multirow[b]{2}{*}{$F$ value } \\
\hline I & II & III & IV & $\mathrm{V}$ & \\
\hline $315 \underset{(6)}{ \pm} 113$ & $601 \underset{(3)}{ \pm} 301$ & $536 \underset{(9)}{ \pm} 116$ & $464 \underset{(6)}{ \pm} 133$ & $311 \underset{(4)}{ \pm} 97$ & $F_{4,23}=0.74$ \\
\hline
\end{tabular}

Values are mean \pm s.e.m. for the no. of follicles in parentheses.

Table 6. The concentration of inhibin $(\mathrm{kU} / \mathrm{ml})$ in 'non-atretic' and 'atretic' small $(<3.5 \mathrm{~mm})$ and large ovine follicles $(\geqslant 3.5 \mathrm{~mm})$

\begin{tabular}{cccc}
\hline $\begin{array}{c}\text { Follicle } \\
\text { diam. }\end{array}$ & 'Non-atretic' & 'Atretic' & $t$ values \\
\hline Small $(<3.5 \mathrm{~mm})$ & $8.8 \pm 1.6(16)$ & $6.9 \pm 1.0(7)$ & $\begin{array}{c}0.763 \\
(\text { d.f. }=21) \\
1.513\end{array}$ \\
Large $(\geqslant 3.5 \mathrm{~mm})$ & $16.2 \pm 3.5(6)$ & $10.6 \pm 2.0(14)$ & $\begin{array}{c}1.513 \\
(\text { d.f. }=18)\end{array}$ \\
\hline
\end{tabular}

Values are mean \pm s.e.m. for the no. of follicles in parentheses.

Oestrogen production has been used as an indicator of the health of the follicles (McNatty, Moore Smith, Osathanondh \& Ryan, 1979; McNatty, 1981; Carson et al., 1981). When aromatase activity in the granulosa cells (pmol oestradiol- $17 \beta / 10^{6}$ viable cells $/ \mathrm{h}$ ) and oestradiol- $17 \beta$ concentration of the follicular fluid were measured, inhibin concentration $(\mathrm{kU} / \mathrm{ml})(y)$ and content (U/follicle) $(z)$ were positively correlated with aromatase activity $(x)$ in large follicles $(\ln y=0 \cdot 30$ $\ln x+1.54 ; r=0.74 ;$ d.f. $=13 ; P<0.01: \ln z=0.23 \ln x+5.30 ; r=0.71 ;$ d.f. $=13 ; P<0.01$, respectively) but not in small follicles $(r=0.09 ; r=0.20)$. There was also a positive correlation between inhibin $(y)$ and oestradiol-17 $\beta(x)$ concentrations in fluid of large follicles $(\ln y=0.35 \ln x$ $+1 \cdot 22 ; r=0.71 ;$ d.f. $=13 ; P<0.01)$, but not in small follicles $\left(r_{\text {enti }}=0.46\right)$. 


\section{Discussion}

We have shown that the inhibin content of follicular fluid from individual follicles varied with follicular fluid volume (and follicular diameter) but not with the degree of atresia assessed by morphological criteria. Inhibin concentration was not related to atresia, but was correlated with follicular fluid volume (and diameter). However, aromatase activity in granulosa cells or oestradiol$17 \beta$ concentration of follicular fluid, considered good indices of atresia (McNatty, 1981; Carson et al., 1981), were highly correlated with both inhibin content and concentration, but only in large follicles ( $\geqslant 3.5 \mathrm{~mm}$ diam.).

It is difficult to compare the inhibin levels measured by us with many other reports because most studies have been on pooled follicular fluid and there is a lack of uniformity amongst inhibin standards and sample preparation, particularly treatment with charcoal. Concentrations of charcoal in excess of $1 \mathrm{mg} / \mathrm{ml}$, millipore filtering and freeze drying can result in considerable loss of inhibin activity (V. W. K. Lee, unpublished observations). The values reported in this paper are up to 10 -fold higher than some data in our preliminary communication on ovine follicular fluid pools (Scott et al., 1980a) and in bovine follicular fluid (Henderson \& Franchimont, 1981). These differences in inhibin activity can be attributed in part to the differences in charcoal treatments, as shown by the results in Table 3 , and the dilution of inhibin before charcoal treatment (V. W. K. Lee, unpublished observations).

Actively growing sheep and human follicles are characterized by an exponential increase in the number of granulosa cells and a concomitant increase in antral fluid volume (McNatty 1981; Tsonis \& Findlay, 1981). In the later stages of growth, antral fluid volume increases at a faster rate than granulosa cell number (McNatty, 1981; C. G. Tsonis, unpublished observations). Granulosa cells have been shown to be a source of inhibin in the follicle of the rat (Erickson \& Hsueh, 1978), cow (Henderson \& Franchimont, 1981), sheep (C. G. Tsonis, unpublished observations) and pig (Anderson, Shander, Channing \& Barraclough, 1979). Therefore, assuming little change in inhibin production per granulosa cell, inhibin content could be expected to increase with the diameter of healthy growing follicles until the LH surge and luteinization, whereas inhibin concentration in sheep follicles might not alter so dramatically because of the increase in antral fluid volume.

There have been few reports in the literature concerning inhibin and its relation to atresia. Although in our preliminary study we noted a decrease in inhibin concentration in pools of ovine follicular fluid from large follicles judged by morphological criteria to be atretic (Scott et al., 1980a) we were unable to confirm this observation when individual follicles were examined. This could be due to the difference in charcoal treatments, to the variability in inhibin content between follicles or to a lack of consistency in assessing atresia by morphological criteria. Because aromatase of granulosa cells is an early casualty in the atretic process (McNatty et al., 1979; McNatty, 1981), measurement of this activity or its product, oestradiol-17 $\beta$ in follicular fluid, has been promoted as a marker of atresia (McNatty, 1981). Channing et al. (1981) noted that inhibin concentrations in follicular fluid of individual human follicles decreased with the oestrogen/androgen ratio. We noted a similar change in inhibin content and concentration with both oestradiol-17 $\beta$ concentration in follicular fluid and aromatase activity in granulosa cells, but only in large $(\geqslant 3.5 \mathrm{~mm})$ follicles. The lack of a similar relationship in small follicles could have been due to the fact that healthy, growing small follicles can be 'androgenic' because of relatively low aromatase activity and hence oestradiol content (Moor, Hay, Dott \& Cran, 1978; Carson et al., 1981). Therefore the use of details of oestrogen production for assessing follicular atresia may not be applicable to these small follciles. Channing et al. (1981) also failed to observe a correlation of oestrogen and inhibin content in follicular fluid of small human follicles. Resolution of this problem awaits estimates of inhibin production by granulosa cells of small atretic and non-atretic follicles.

This project was supported by the Australian Meat Research Committee and the National Health and Medical Research Council of Australia. We thank Dr Gordon Baker for OTLP standard; NIH for radioimmunoassay standards; and Fay $_{\text {Lerman }}$ for $_{C}$ secretarial $_{\text {assistance }}$ 23 02:02:55PM 


\section{References}

Anderson, L.D., Shander, D., Channing, C.P. \& Barraclough, C.A. (1979) Evidence that porcine granulosa cells are the possible source of "inhibin-F". Endocrinology 104A, p. 244, Abstr. 686.

Borth, R. (1976) Statistics of parallel-line assay. In Methods of Hormone Analysis, p. 500. Eds H. Breuer, D. Hamel \& H. L. Kruskemper. Thieme Verlag, Stuggart.

Carson, R.S., Findlay, J.K., Burger, H.G. \& Trounson, A.O. (1979) Gonadotropin receptors of the ovine ovarian follicle during follicular growth and atresia. Biol. Reprod. 21, 75-87.

Carson, R.S., Findlay, J.K., Clarke, I.J. \& Burger, H.G. (1981) Estradiol, testosterone and androstenedione in ovine follicular fluid during growth and atresia of ovarian follicles. Biol. Reprod. 24, 105-113.

Channing, C.P., Anderson, L. \& Hodge, G.D. (1980) A search for inhibin activity in monkey ovarian vein blood (OVB) and follicular fluid (FFI). Proc. 6th Int. Congr. Endocr. Melbourne, Abstr. No. 178.

Channing, C.P., Gagliano, P., Hoover, D.J., Tanabe, K., Batta, S.K., Sulewski, J. \& Lebech, P. (1981) Relationship between human follicular fluid inhibin F activity and steroid content. J. clin. Endocr. Metab. 52, 1193-1198.

Chari, S., Hopkinson, C.R.N., Daume, E. \& Sturm, G. (1979) Purification of "inhibin" from human ovarian follicular fluid. Acta endocr., Copenh. 90, 157-166.

Cummins, L.J., O'Shea, T., Bindon, B.M., Lee, V.W.K. \& Findlay, J.K. (1983) Ovarian inhibin content and sensitivity to inhibin in Booroola and control strain Merino Ewes. J. Reprod. Fert. 67, 1-7.

de Jong, F.H. \& Sharpe, R.M. (1976) Evidence for inhibin-like activity in bovine follicular fluid. Nature, Lond. 263, 71-72.

Eddie, L.W., Baker, H.W.G., Higginson, R.E. \& Hudson, B. (1979) A bioassay for inhibin using pituitary cell cultures. J. Endocr. 81, 49-60.

Erickson, G.F. \& Hsueh, A.J.W. (1978) Secretion of "inhibin" by rat granulosa cells in vitro. Endocrinology 103, 1960-1963.

Goodman, R.L., Pickover, S.M. \& Karsch, F.J. (1981) Ovarian feedback control of follicle stimulating hormone in the ewe. Evidence for selective suppression. Endocrinology 108, 772-777.

Henderson, K.M. \& Franchimont, P. (1981) Regulation of inhibin production by bovine ovarian cells. $J$. Reprod. Fert. 63, 431-442.
Lee, V.W.K., McMaster, J., Quigg, H., Findlay, J. \& Leversha, L. (1981) Ovarian and peripheral blood inhibin concentrations increase with gonadotropin treatment in immature rats. Endocrinology 108, 24032405.

Lorenzen, J.R., Dworkin, G.H., Schwartz, N.B. \& Channing, C.P. (1978) The differential ability of porcine follicular fluid suppress FSH in intact and castrate prepuberal and adult male rats. Endocrino$\log y$ 102A, 97, Abstr. 46.

Lowry, O.H., Rosebrough, N.J., Farr, A.L. \& Randall, R.S. (1951) Protein measurement with the Folin phenol reagent. J. biol. Chem. 193, 265-275.

Main, S.J., Davies, R.V. \& Setchell, B.P. (1979) The evidence that inhibin must exist. J. Reprod. Fert., Suppl. 26, 3-14.

Marder, M.L., Channing, C.P. \& Schwartz, N.B. (1977) Suppression of serum follicle stimulating hormone in intact and acutely ovariectomized rats by porcine follicular fluid. Endocrinology 101, 1639-1642.

MeNatty, K.P. (1981) Hormonal correlates of follicular development in the human ovary. Aust. J. biol. Sci. 34, 249-268.

MeNatty, K.P., Moore Smith, D., Osathanondh, R. \& Ryan, K.J. (1979) The human antral follicle: functional correlates of growth and atresia. Annls Biol. anim. Biochim. Biophys. 19, 1547-1558.

Moor, R.M., Hay, M.F., Dott, H.M. \& Cran, D.G. (1978) Macroscopic identification and steroidogenic function of atretic follicles in sheep. $J$. Endocr. 77, 309318.

Scott, R.S., Quigg, H., Trounson, A.O., Tsonis, C.G. \& Findlay, J.K. (1980a) Inhibin in ovine follicular fluid. Proc. Endocr. Soc. Aust. 23, 67.

Scott, R.S., Burger, H.G. \& Quigg, H. (1980b) A simple and rapid in vitro bioassay for inhibin. Endocrinology 107, 1536-1542.

Tsonis, C.G. \& Findlay, J.K. (1981) Aromatase activity, steroid content and atresia in ovine follicles. Proc. Endocr. Soc. Aust. 24, 75.

Welschen, R., Hermans, W.P., Dullaart, J. \& de Jong, F.H. (1977) Effects of an inhibin-like factor present in bovine and porcine follicular fluid on gonadotrophin levels in ovariectomized rats. J. Reprod. Fert. 50, 129-131. 